\title{
From farmer to dairy farmer: Swedish dairy farming from the late 1920 s to 1990
}

\author{
CARIN MARTIIN
}

KEYWORDS: dairy farming, commercialization, intensification, dairy consumption.

JEL CODES: N34, N54, Q12, Q18.

wedish dairy farming became increasingly commercialized up until the mid$\circlearrowleft$ twentieth century, when nine out of ten farmers supplied milk to dairy plants. They adopted the view that milk sales were the path to progress for agriculture and the countryside in times of urbanization. Dairy farming was obviously embedded in functions that went beyond food production, which complicated the situation when the surplus of dairy farmers led to overproduction. At the same time, domestic demand became saturated and the international butter market proved more challenging than expected. This article focuses on collective outcomes of farmers' actions in terms of commercialization, intensification, specialization and geographic concentration from the late 1920s to 1990. The timeframe includes an expansive phase until the late 1940s, which was followed by decades of declining demand for milk and a more restrictive political policy toward agricultural surpluses. It is argued that the vision of dairy farming as a safe way to make a living in agriculture underestimated the potential for increased production and limited demand. Contrary to initial hopes of using milk as a way to save the countryside, increasingly intensive and specialized dairy farming served to drive many out of farming. 


\section{De campesino a ganadero de leche: la ganadería de leche en Suecia entre finales de la década de 1920 y 1990}

\section{PALABRAS CLAVE: ganadería de leche, comercialización, intensifi- cación, consumo lácteo.}

\section{CÓDIGOS JEL: N34, N54, Q12, Q18.}

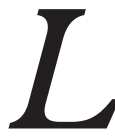

a ganadería sueca de leche experimentó una comercialización creciente en el periodo previo a mediados del siglo XX, cuando nueve de cada diez ganaderos proporcionaba leche a industrias lácteas, siguiendo ideas sobre la venta de leche como vía de progreso para la agricultura y el medio rural en tiempos de urbanización. De manera obvia, la ganadería de leche estaba incorporada dentro de funciones que iban más allá de la producción de comida. Esto complicó las cosas cuando pronto demasiados ganaderos estaban produciendo demasiado, dado que la demanda doméstica estaba saturada y el mercado internacional de la mantequilla se ponía más difícil de lo esperado. El artículo se centra en los resultados colectivos de las actuaciones de los ganaderos en términos de comercialización, intensificación, especialización y concentración geográfica entre finales de la década de 1920 y 1990. El periodo incluye una etapa expansiva hasta finales de la década de 1940, que fue seguida por décadas marcadas por una demanda de leche declinante y una actitud politica menos generosa en lo que se refería a aceptar excedentes agrarios como modo de preservar la ganadería de leche. Se argumenta que la visión de la ganadería de leche como forma segura de ganarse la vida dentro del sector agrario parece haber subestimado, tanto el potencial para aumentar la producción como las limitaciones de la demanda, y que la ganadería de leche intensiva y especializada terminó siendo un factor de expulsión del sector agrario, en buena medida lo contrario de lo que planteaba la visión inicial de la leche como forma de salvar al medio rural.

Received: 2016-01-18 - Revised: 2017-04-03 - Accepted: 2017-04-06

Carin Martiin is Associate Professor in Agrarian History at the Swedish University of Agricultural Sciences. Address: Division of Agrarian History, Department of Urban and Rural Development, Box 7012, SE75007 Uppsala (Sweden).E-mail: carin.martiin@slu.se 


\section{INTRODUCTION}

Between the late 1920s and 1990 Swedish dairy farming expanded and then began to decline from the mid-century onwards. By the middle of the century, more than $90 \%$ of all farmers were dairy deliverers, selling milk to dairy plants, compared with about $25 \%$ in $1990^{1}$. The peaks in volumes produced and the number of dairy farmers in the middle of the century coincided with the point where the urban Swedish population exceeded the rural population ${ }^{2}$. In times of urbanization, industrialization and other large-scale changes in society voices belonging to the dairy sector highlighted the sale of milk as the best way ahead for Swedish farmers and the countryside -a good farmer was an ambitious dairy farmer ${ }^{3}$. Such a strategy depended on high levels of consumption, political support and public acceptance. This occurred, at least in the 1930s and 1940s, when many urban dwellers had family and friends in the countryside, and when political efforts to improve standards of living were aimed at both town and countryside. From the 1950s onwards, Swedish dairy farming has to be seen in a societal context that had an increased focus on modernization and urban and industrial development. In addition, there were political efforts to gradually adapt agriculture to a new reality ${ }^{4}$.

1. The total yearly production of milk in Sweden had increased largely before the beginning of the studied time period and was in $192784 \%$ of the peak level, reached in 1938 and 1950 (StatisticalYearbook of Sweden, yearly volumes).

2. Historisk statistik för Sverige. 1: Befolkning 1720-1967 (1969: 66, t. 14); DovRING (1988: 39).

3. Among these voices was the journal Mjölkpropagandan (The Milk Propaganda), which is referred to several times in this article. Behind was an association that aimed at increased sale of dairy products with reference to health aspects. The board was a strategic mix for lobbying, including influential politicians, medical experts, home economics teachers and others in a strategic mix for lobbying the benefits of dairy products (1924, No. 2). This somewhat controversial association received economic support from the state (JORDBRUKSUTREDNINGEN, 1930: 48) and engaged prominent names, even the Swedish king who presented golden medals to producers of high quality milk. The readership was said to be dominated by farmers, and the content was wide-ranging, including animal husbandry, international dairy trade, milk hygiene, cooking, housework, crosswords, children's' pages, and even pictures from the outside world, e.g. from the Spanish civil war (1936, No. 3, 11). In 1935 the ordinary edition was 35,000 copies, by the editor claimed to be the biggest agricultural journal in Scandinavia (1935, No. 12). The slogan "Better milk-increased consumption" was frequently formulated (e.g. 1925, No. 3, p. 1), and was said to be used by the sister organizations in many other countries in North America and Europe (e.g. 1925, No. 3; 1926, No. 11; 1927, No. 2). The journal has previously been studied in NisKanEN (1995: 64-72), and MARTIIN (2010).

4. For overviews in English on Swedish agrarian history, see MORELl (2011) and Flygare and ISACSON (2011: 214-70); JANSSON (2011), cartography; MARTIIN (2011), dairy farming; MoRELL (1994), food consumption. 
As regards to consumption, the other end of the dairy chain, the general prevalence of dairy cattle in the Swedish countryside had, since long, made milk and dairy products a natural part of everyday life. Traditionally, milk had often been considered a primary product for varying kinds of use, such as fermented milk, butter, cottage cheese, whey cheese and hard cheeses, and as feed for the farm animals. By the beginning of this study fresh milk was frequently used for drinking, pancakes, soups, puddings, porridge, gruel and deserts, and at about similar levels in town and country ${ }^{5}$.

During the time studied for this paper (late 1920s-1990), three periods occurred that relate to three of Malassis' four food consumption models ${ }^{6}$. Traditional use in kind, relating to the second model, was still in practice although on small scale, and was gradually phased out. The model that dominated dairy consumption during the period studied was characterized by extensive consumption of domestically produced milk, cream, butter and cheese, processed in cooperative dairy plants. This model continued through to 1990 , although with a decreasing demand for milk beginning in the late 1940s. Starting in the mid-1960s, the introduction of new product such as low-fat milk presaged changes in consumer preferences. The Swedish dairy market would, however, be a matter of domestic production and consumption until the mid-1990s, when membership of the European Union opened up for international agro-industrial companies to enter the Swedish food market.

This article looks at how farmers acted in terms of commercialization, intensification, specialization and geographic concentration in dairy farming between the late 1920s and late 1940s, and the following decades until 1990 that saw combinations of saturated consumer demand and more negative political attitudes to agriculture and the countryside. It is argued that the view of dairy farming as a way to make a living from agriculture across the country, highlighted by the Milk Propaganda, appears to have underestimated the potentials for increased production and the limitations in demand. Increasingly intensive and specialized dairy farming meant more milk per farm and thus space for fewer and fewer dairy farms over time.

5. RÄNK (1966: 13) as regards milk as raw material; ULMA 1 (questionnaire, traditional use of milk); MARTIN (2008: 177) and NM 82 (questionnaire) as regards milk paid to contract farm workers); MARTIIN (2005: 121) about milk as feed. WALLENSTEEN-JÆGER $(1973: 21,28)$ about milk consumption in the 1920s and later decades. Levels of consumption in town and country with reference to Statistisk årsbok för Sverige (1938: 234, t. 178), which presents average consumption in low and middle class households in towns (1922-28) and in farm households in 1920 and 1933-34.

6. Malassis (1988: 195); Collantes (2015: 249); FonTE (2002: 15). 
The paper makes a few basic comparisons between Sweden and Denmark, the early commercialized and world-famous butter exporter, and Spain, where the commercialization of milk production occurred later than in Sweden. Among some characteristics to consider when studying Swedish dairy farming of the twentieth century in an international context are: its vast and sparsely populated countryside; the many small independent farm holdings; a sufficient domestic food supply, generally speaking, since the 1930s; low export objectives; freedom from the atrocities and cruelties of war; a supportive Swedish state with welfare goals and from the mid-century aiming at a modern urban and industrial country.

When this study begins, by the late 1920s, representatives in the dairy sector looked ahead with increased confidence, expecting successful dairy exports like in the early 1910s, together with increased urban demand for dairy products ${ }^{7}$. A few years later farming experienced huge economic problems and the entering of an era of regulation and other kinds of state engagement. When the study ends, by 1990, the opposite was the case. By then the agricultural sector was on the brink of a new reality because of the dismantling of the agricultural regulation system of the early 1930s and an approaching but not yet official application for EU membership.

The first and major part of this article focuses on dairy farming in terms of commercialization and looks at the number of dairy suppliers, the number of dairy cows, milk yield per cow and technologies behind higher yields. The next section, on consumption, focuses on the phasing out of traditional use in kind and an overview of changes in consumption of milk, cream, butter and cheese. The last section shows how Sweden used butter exports as a buffer to manage imbalances between supply and demand, an undesirable but still accepted side effect of the idea to turn almost all Swedish farmers into dairy farmers. The study is to a great extent based on official Swedish statistics, complemented by surveys of agricultural magazines and SOU reports (Swedish government official reports).

Figure 1 shows Sweden and its major agricultural regions. Dairy farming was operated across the country between the late 1920s and 1990, with the exception of the Arctic mountains in the northwest. The length of the country from south to north is 1572 kilometres and the population was 6.1 million people in the late 1920 s and 8.6 million in 1990 .

7. SOU (1930: 2, 8); Mjölkpropagandan (1925, No. 11, p. 203; 1928, No. 4, p. 63; 1929, No. 1, p. $24 ; 1929$, No. 5 , p. 80). 


\section{Sverige \\ Sweden \\ Indelningen i 8 \\ produktionsområden}

The division in 8

production areas

1 The southern plainland areas of Götaland (Gss)

2 The transitional areas of Götaland $(\mathrm{Gmb})$

3 The northern plains of Götaland (Gns)

4 The Svealand plainlands (Ss)

5 The forest areas of Götaland (Gsk)

6 The forest areas of Central Sweden (Ssk)

7 Lower Norrland $(\mathrm{Nn})$

8 Upper Norrland (Nö)

\section{FIGURE 1}

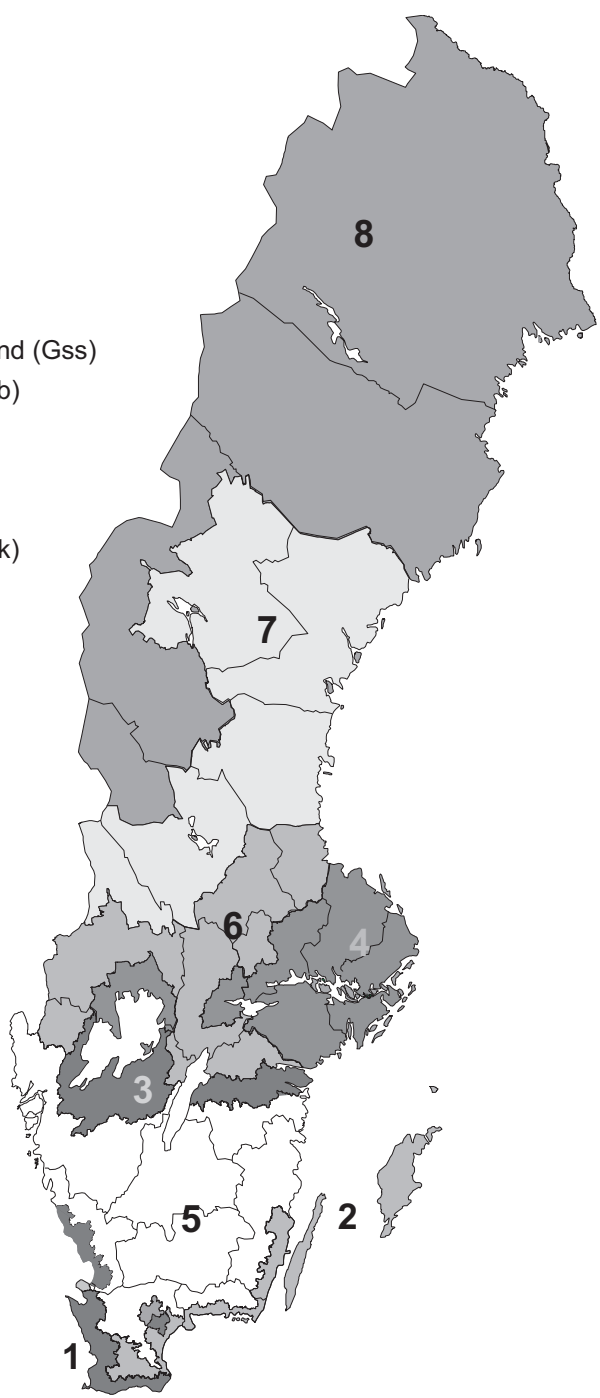

Source: fordbruksstatistisk årsbok (2013, Appendix 2, p. 350).

\section{CHANGES IN SWEDISH DAIRY FARMING}

\subsection{Increasing volumes of milk for sale}

For centuries, and even millennia, the primary reason for having dairy cattle in Sweden was to provide food for the producer household and various kinds of inputs for farming, 
such as manure, draught power and offspring, and the occasional sale of surpluses ${ }^{8}$. This traditional form of agriculture was accompanied by commercial butter production for export in the latter part of the nineteenth century when several Swedish dairy producers, primarily bigger farms, followed the footsteps of their Danish colleagues, although with a less purposeful approach ${ }^{9}$. In Denmark, in the late nineteenth century, almost $90 \%$ of the total milk production was supplied to dairies, a level Sweden did not reach until the early 1960s. As for Spain, a turning point in selling milk to dairy plants has been estimated to have occurred around $1965-75^{10}$.

In the late $1920 \mathrm{~s} 41 \%$ of the $98 \%$ of the farms that had dairy cows, supplied the milk to dairy plants, and less than $50 \%$ of the total production was delivered to dairy plants ${ }^{11}$. For the total Swedish production and quantities supplied between 1913 and 1990, see Figure 2.

FIGURE 2

Total production of milk and shares supplied to dairy plants $(1913-90)^{\star}$ (in tonnes)

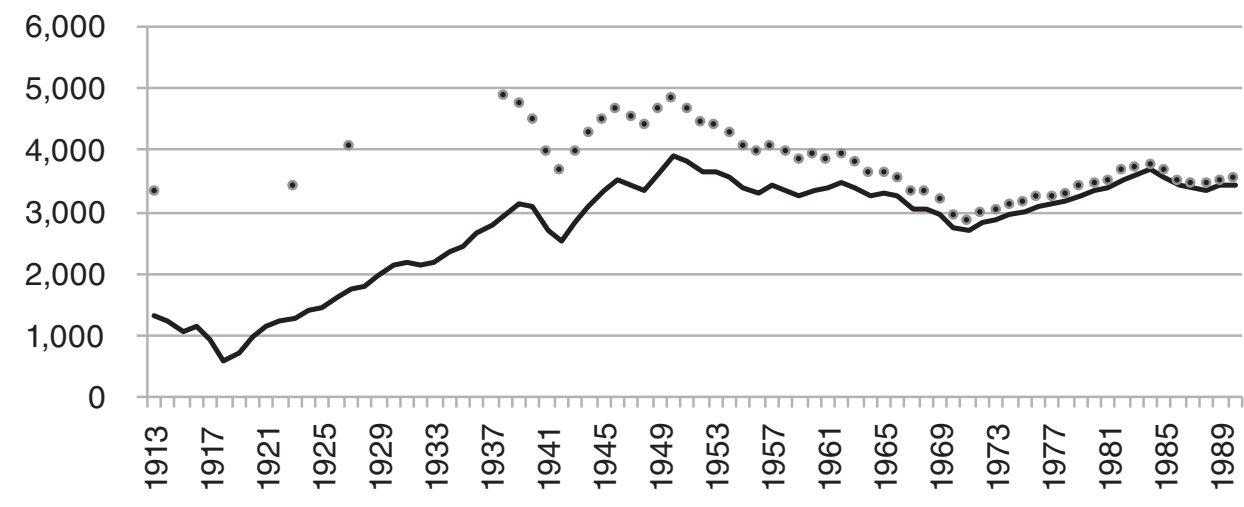

- Total production To dairies

^Kilogram is common in Swedish statistics, litre is often used in practice.

Sources: SOU (1930: 4, 2, t. 2); Statistisk årsbok för Sverige (1941-92).

The gap between the two lines in Figure 2 occurred for two reasons: the number of farms with dairy cows that were not yet connected to a dairy plant, and the amounts of milk

8. Myrdal (2011: 86-8); MARTIIN (2005: passim).

9. MARTIIN (2016).

10. Collantes, unpublished draft, generously shared with the author, autumn 2016.

11. Fordbruk och boskapsskötsel (1949: 35); Statistisk årsbok för Sverige (1929: 80-1, t. 78; 94, t. 87); SOU (1930: 2). 
that farms connected to a dairy plant were keeping for themselves. From the late 1930s onwards, the gap decreased, and from the 1960s onwards the total and supplied volumes were almost the same. Moreover, the record highs of 4.9 and 4.8 billion kg total Swedish production in 1938 and 1950, respectively, can be compared with with the slightly higher Danish levels of 5.4 billion kg in both 1938 and 1950, just below the peak of 5.5 billion $\mathrm{kg}$ in 1931. In Spain in 1950 the total production of milk from dairy cows was 38\% of the Danish and 43\% of the Swedish levels. Two decades later, in 1972, the Spanish volumes had grown to the same level as in Denmark and were $50 \%$ above the then record low Swedish level ${ }^{12}$.

The low total output during the First and Second World Wars and in the late 1940s (Figure 2) is primarily explained by weather-related harvest failures, chiefly droughts. The low level in the early 1970s is explained by a drastic reduction in dairy cattle in the 1960s (Figure 5), too drastic even in the eyes of the authorities. The significant increase in the 1980s was caused by combination of the authorities' temporary encouragement of milk production and a strong response among dairy farmers, which soon resulted in new surpluses. This time, in the mid-1980s, the government decided to try another tool, individual milk quotas per farm, which explains the temporary downturn in the late $1980 \mathrm{~s}^{13}$.

\subsection{High focus on the number of dairy farmers in Sweden}

In the Swedish case a great deal of attention was paid to changes in the number of farmers, which had social, regional and emergency effects ${ }^{14}$. Figure 3 illustrates this, and the diminishing gap between the number of farms with dairy cows and the number of dairy suppliers (solid line). Both Figures 2 and 3 are extended back to 1913 to give an idea of the situation just before the late $1920 \mathrm{~s}$.

12. Statistisk årsbok för Sverige (table "Animal production", annual); Denmark: Landbrugsstatistik 1900-1965 (74-5, t. 41); Landbrugsstatistik 1976 (193, t. 12.1); MINISTERIO DE AGRICULTURA (1974: 468). No figures include milk from sheep and goats, which provided for $16 \%$ of the total Spanish milk production in 1950 and $12 \%$ in 1970, but was minimal in Denmark and Sweden.

13. Husdjur (1970-90).

14. Detailed official dairy statistics from 1913 onwards indicate an official interest in the development of the dairy sector, such as the increased numbers of dairy suppliers before the mid-twentieth century and in the following decline. Social, regional and emergency considerations are for example expressed in SOU (1955: 144, 254-55); SOU (1977: 37, 160, 174, 396); SOU (1984: 383). 
FIGURE 3

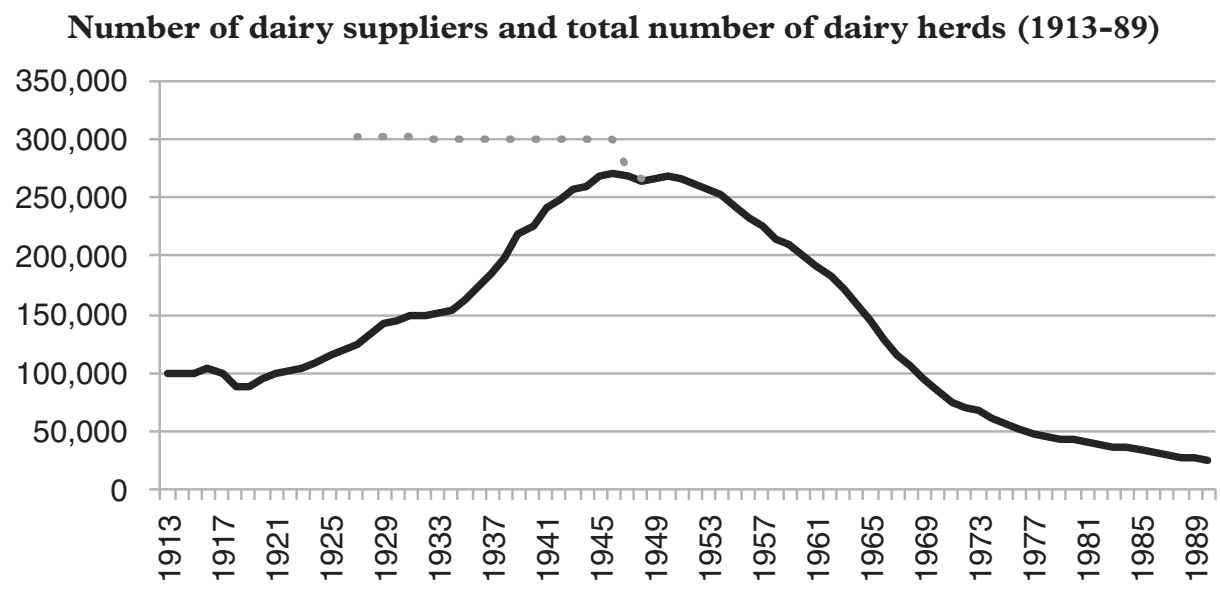

No of suppliers $\quad \cdots$ No of farms with dairy cattle

Sources: Mejerihantering (1913-39); fordbruk och boskapsskötsel (1949: 35); Statistisk årsbok för Sverige (1929-90).

As shown in Figure 3, the number of dairy suppliers rose in the late 1920s, mirroring a wider interest in producing milk for sale. This interest dropped around 1930 when the international butter price fell and reduced the Swedish milk price as well. The confidence in commercial dairy farming returned, however, when the government stepped in and, among other things, guaranteed a minimum price to farmers and agreed to introduce an agricultural regulation system ${ }^{15}$. What is more, the regulation system favoured the cooperative dairies on expense of other forms. The system included the collecting of fees on all milk sold; fees, used to subsidise the butter export and thus sheltered the domestic milk price from the then falling world market butter price. Only cooperatives were allowed to collect the fees, which contributed to give cooperative dairies practically monopoly of the supply of milk to retailers.

The state engagement was thought to be temporary but was in fact maintained for 60 years, and expanded and became more complex over time. After a huge increase in the 1930 s, substantially stimulated by the strong development of dairy cooperatives to which $86 \%$ of the dairy producers were connected in 1939 , the number of dairy suppliers peaked

15. The regulation system and the negotiations around them in the early 1930s (including the wellknown "horse trading" between the Social Democrats and Bondeförbundet (the farmers' party) in 1933 has been given much attention in Swedish research. See GulbrandSEN and LiNDBECK (1969: 263-71); HEDLUND and LUNDAHL (1985: 52-80); HELLSTRÖM (1976: 320-401, 576-85, 627-46, 64760); KYLEBÄCK (1979: 86-103); MORELL (2011: 211); STENSGÅRD (1957: 106-16). 
in 1946 at the impressive level of 271,000 connected farm holdings ${ }^{16}$. By that time nine out of ten Swedish farmers were dairy farmers, living and working on farms of all sizes across the Swedish countryside. The regular income from milk was important for the entire rural population, which accounted for two million of the total Swedish population of seven million people by the mid-twentieth century ${ }^{17}$. In Denmark the total population was four million and the number of dairy farms 200,000 from which the production was of greatest importance for the Danish foreign trade, contrasting with the Swedish focus on domestic consumption ${ }^{18}$. Starting in the mid-1950s, Denmark and Sweden experienced a similar decline in the number of dairy producers; roughly speaking they were found at all farms in the 1940s, on every second Danish and Swedish farm in 1970 and on every fourth farm in $1990^{19}$. As regards Spain, it has been suggested that the number of dairy farmers peaked by the mid-1970s, three decades later than in the two Scandinavian countries, and began to decline around $1980^{20}$. The numbers of Danish dairy farmers managed to remain high from the late nineteenth century to the mid-twentieth century before beginning to decline, whereas their Swedish colleagues experienced a short peak period at the turn of the mid-twentieth century. A similar observation might be made for Spain, although it happened later, which suggests that commercial dairy farming was used as a way to involve and make use of agriculture and the countryside for a limited time during a process of urbanization.

\subsection{Herd sizes and regional distribution}

Commercialization in dairy farming was not limited to bigger farms, as the available statistics reveal. Complete statistics are not available but according to figures for dairy cooperatives in 1927 and 1939, as many as 30\% of the suppliers were smallholders, with 13 dairy cows. The share was lower than the total number of smallholders, but still indicates that the Swedish dairy farmer could definitely be a smallholder ${ }^{21}$. The cooperative dairy form, "the producer co-operative movement", certainly played a role in small

16. Mejerihantering (1925: 22, t. 2; 1929: 26, t. 2; 1939: 16, t. 2).

17. Statistisk årsbok för Sverige (dairying and population), annual volumes; fordbruksstatistisk årsbok (1970: 46-7, t. 2); GuLBRANDSEN and LINDBECK (1969: 18).

18. BJøRN (1988: 16).

19. Denmark: BJøRN (1988: 16); Landbrugsstatistik 1990 (1991: 8, t. 1.2; 132, t. 11.1; 133, t. 11.2. Sweden: Statistisk årsbok för Sverige (1971: 87, t. 64; 97, t. 80; 1992: 68, t. 64; 69, t. 66).

20. Collantes (2016).

21. Mejerihantering (1927: 26, t. $2: 16$, t. 2$)$. 
holdings selling to dairy plants ${ }^{22}$. Smallholder dairy farming remained important until the early 1950s, when two thirds of all Swedish farm holdings were in the 2-5 and 5-10 hectare categories and produced $40 \%$ of all milk. In contrast, only $3 \%$ of all farms had more than 50 hectares and they provided $14 \%$ of all milk, which meant they supplied higher amounts per farm but not much from a national perspective. In the late 1960s, half of the then remaining total number of farms were in the 2-5 and 5-10 hectare categories and still produced more of the total milk production than the farms with more than 50 hectares, $22 \%$ and $17 \%$ respectively ${ }^{23}$. In spite of their long dominance the small herds were phased out. At the same time, the total number of herds declined and only the two categories with bigger herd sizes grew, as shown in Figure 4. One reason for the long continuation of smallholder dairy farming is that many farmers continued keeping their dairy cows until retirement, sometimes longer ${ }^{24}$.

\section{FIGURE 4}

Number of dairy herds of different size categories (1965-90)

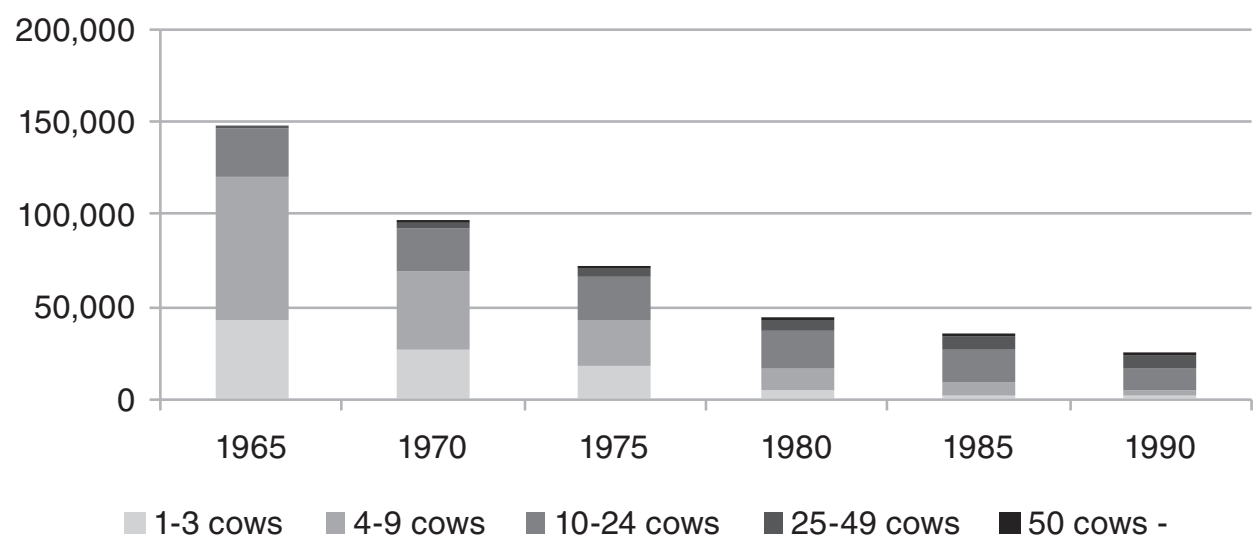

Sources: Statistisk årsbok för Sverige (1970: 94, t. 68; 1973: 96, t. 72; 1978: 108, t. 87; 1982-83: 100, t. 77; 1989: 67, t. 61; 1995: 75, t. 73).

The decline from about 270,000 to 25,000 dairy suppliers between the mid-1940s and 1990 (Figure 3) occurred for many other reasons in addition to farmers retiring. According to the economist and agronomist C-E Odhner, dairy farmers kept their herds as long as no other jobs were available, almost irrespective of the current milk price and talk about

22. MORELL (2011: 209).

23. Fordbruksstatistisk årsbok (1970: 46-7, t. 2); LEBERT and ÅKERBLom (1969: 9, t. 4).

24. Lantbruksräkningen 1981 (1983: 690, t. 4.8). According to SOU (1946: 23-4) the processes of structural rationalization was expected to involve a long period of transition, largely related to generation shifts. 
a more comfortable life in town ${ }^{25}$. The milk price was however important when influenced by other aspects too, such as the seasonal harvest, personal interest or non-interest in dairy farming versus other alternatives, feelings of farm trusteeship over the generations and other ties to the local countryside. Whether farmers who ended up with milk production kept on farming in other ways, or left farming altogether, has not been studied in detail. A more rapid decline in number of dairy herds than number of farms suggests, however, that some former dairy farmers stayed on the farm and made a living on, for example, off farm job in combination with a small herd of beef cattle, a kind of animal husbandry that increased in parallel with the declining number of dairy herds ${ }^{26}$.

The Swedish geography and its long distances add an important dimension to the Swedish case. Regional balance and a populated countryside was being debated at the same time as Sweden experienced far-reaching urbanization, depopulation of the countryside and structural rationalization in agriculture. In this context dairy farming was often considered important for the local society as well as for emergency measures. In spite of political efforts from 1947 onwards to encourage structural rationalization in farming, including fewer dairy farms, the government did not want dairy farming to end in any part of the country ${ }^{27}$. Therefore some dairy farms in each parish were stimulated to expand and rationalize in order to be the ones to continue in the future which means that, from the mid-century onwards, each parish had a local concentration of production with fewer milk producers. In the 1970 regional considerations were given much attention, which contributed to a temporary toning down of the government's expectations on rationalization ${ }^{28}$. When the study ends by 1990 one could expect to find dairy farming in most parishes across the country.

Regional differences were also visible. A more rapid decline in the number of dairy farms took place in the plains where the fertile soils made other kinds of farming possible, such as profitable production of sugar beet, oil seed and winter wheat. In addition, shorter distances to diverse labour markets offered several job alternatives. Moreover, the decline was higher in the forested middle parts of the country, while dairy farming was more often continued in the mosaic and forest landscape in the south (Figure 1, region $5)^{29}$.

25. ODHNER (1953: 104-5, 108); BÄCKLUND (1988:215-17).

26. Fordbruksräkningen (1961: 372, t. 17; 1981: 665, t. 4.5).

27. SOU (1977: 37, 160, 174); SOU (1984: 22, 26); HEDLUND and LUNDAHL (1986).

28. SOU (1977: 113, 311$)$.

29. Fordbruksräkningen (1961: 312-15, t. 8; 1981: 478-81, t. 4.1); Fordbruksstatistisk årsbok (1991: 140). 


\subsection{Changes in number of dairy cows and yield per cow}

As the number of Swedish dairy farms began to decline by the mid-century, so did the total number of dairy cows, although the latter was partly counteracted by an increase in the size of the remaining herds. The record high of two million dairy cows in 1931 had fallen to 0.76 million in 1970; in Denmark the national herd went down from 1.7 to 1.1 million. In contrast, Spain, which was still building up the dairy sector, increased its number of dairy cows from 1.1 million dairy cattle in 1955 to 1.8 million in $1970^{30}$.

FIGURE 5

Total number of dairy cows and kilograms of milk per cow per year (1927-90)

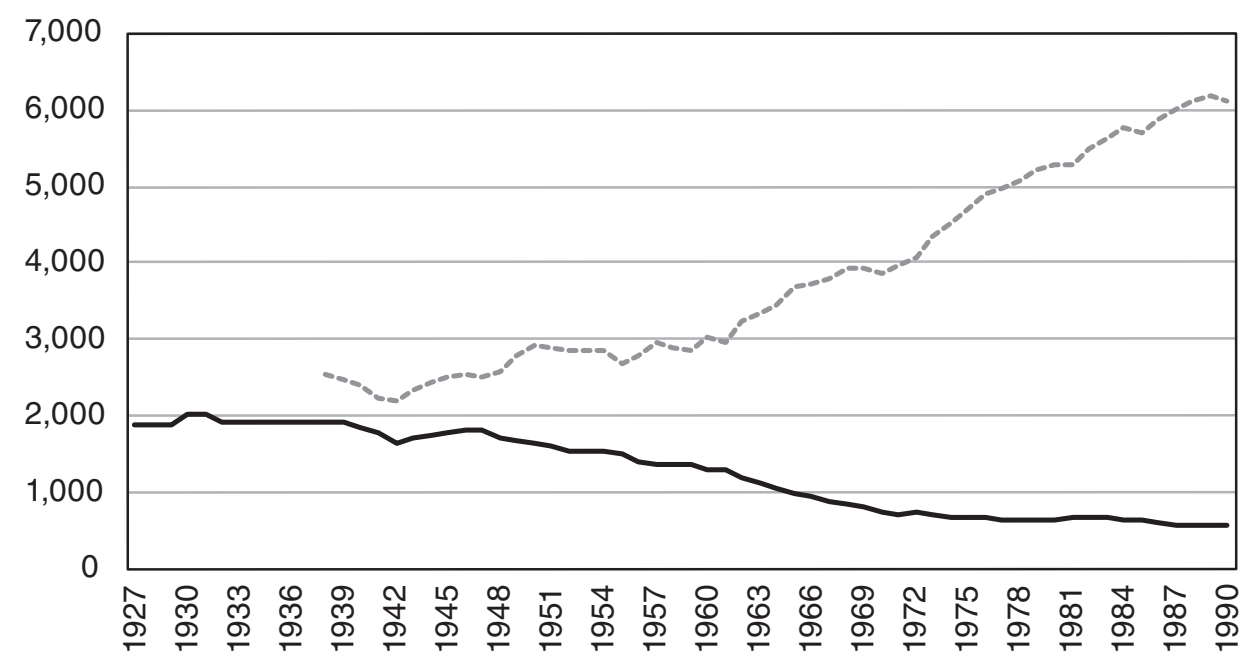

Dairy cows, 1000 heads ------.. Milk per cow

Source: Statistisk årsbok för Sverige (1929-91).

At the same time as the number of Swedish dairy cows declined, the average milk yield per cow rose, which served as a driver for continued reduction in the number of dairy cows. The average yield per animal per year increased from 2,200 kg to 6,100 kg from the late 1920s to 1990 , most of which occurred in the 1970s and 1980s. This was just after the drastic reduction in the number of dairy cows (40\% in ten years) in the 1960 s. The increase in yield counteracted this decline in the number of animals and the drop

30. Sweden: Statistisk årsbok för Sverige (1937: 94, t. 77; 1973: 98, t. 76). Denmark: Landbrugsstatistik 1900-1965 (1969: 8, t. 1; Landbrugsstatistik 1976 (1977: 154, t. 11.1). Spain: MINISTERIO DE AGRICULTURA (1974: 470). 
in the numbers of dairy farms ${ }^{31}$. The diverging trends in the number of animals and average yields are illustrated in Figure 5.

As Swedish dairy farming intensified the remaining farms increasingly specialized in dairy production, keeping only dairy cattle. Step by step they stopped keeping the previously common combinations of cattle, pigs, poultry and sometimes sheep, plus draught horses, in favour of a somewhat bigger dairy herd. According to an example from the end of the time period, dairy and pig farming was combined at $27 \%$ of the dairy farms in 1979 but only $16 \%$ in $1990^{32}$. This increased dependence on milk, and because of the milk price this may have been the best possible strategy at the time. The combined effect of intensification and specialization was clearly mirrored in increased supplied volumes per farm. In 1960 the average sale per dairy farm was about 16,000 kg per year, or $44 \mathrm{~kg}$ per day. This was doubled each of the following decades, to 32,000 kg in 1970, 79,000 in 1980 and 138,000 in $1990^{33}$.

Behind the increased average yields per cow and substantially enlarged quantities per dairy farm were the cumulative effects of successive phasing out of low-yielding herds, an increased focus on high yields, and the impact of technical improvements. The use of new technologies was in line with a technology friendly atmosphere in the 1950s and 1960s, which was heavily promoted by the social democratic Prime Minister Tage Erlander. This was also emphasized in the official report behind the 1947 agricultural programme where it was said that technical progress should always be welcomed, even when contributing to increased problems with overproduction ${ }^{34}$.

\subsection{Technologies behind higher milk yields}

One of the yield-increasing technologies was artificial insemination (AI), which in the case of Sweden was used for approximately $25 \%$ of the dairy cattle in $1950,40 \%$ in $1960,70 \%$ in 1970 and about $85 \%$ in $1990^{35}$. Through AI farmers had access to scientifically based animal breeding and genes with the potential for higher milk yields. At the same time

31. Average yields calculated on basis of total Swedish milk production and total number of dairy cows. All figures from Statistisk årsbok för Sverige, annual volumes.

32. Fordbruksstatistisk årsbok (1980: 273, t. 117; 1991: 145, t. 9.11).

33. Calculated on the basis of total quantities to dairy plants and number of dairy suppliers (Statistisk årsbok för Sverige, annual volumes).

34. ERLANDER (1976: 32-6); SOU (1946, 42: 116-7).

35. Helmenius and EkesBo (1969: 104, 106); fordbruksstatistisk årsbok (1991: 150, fig. 9.19). 
two breeds, the Swedish Red-and-White (SRB) and the black and white Swedish lowland (SLB) increased in size at the expense of traditional breeds, which among other things contributed to higher average yields ${ }^{36}$. In addition, the farm visits by the AI-assistants were an opportunity to share knowledge about production issues, such as feeding routines, hay quality and indoor environment, and so, served as a channel for mutual feed back between farmers, advisers and scientists ${ }^{37}$. This contributed to continuous improvements, including higher milk yields. Moreover, the pace at which old dairy cows were replaced, increased substantially. This was motivated by the argument that scientific breeding and AI-technology made each generation better than the previous one. Following this idea the recruitment per centage rose from about $20 \%$ in 1960 to $30 \%$ in 1970 and up to $40-45 \%$ by the end of the period studied ${ }^{38}$. Even though the heifers were generally born and bred at the farm, they required two years of feeding, housing and many work hours before they began to pay back costs, and the outcome in each case was far from guaranteed.

A more indirect means of increasing yield was the introduction of electric lights between the 1920 s and the mid-century and later the installation of hot water, electric ventilation and fluorescent lightning ${ }^{39}$. The impact of such improvements were, however, counteracted to some extent by efforts to save time, at the expense of animal welfare, especially from the 1960s onwards, when time and motion studies suggested simplifying feeding routines, doing less or no grooming and using less or no straw on the concrete floor in the cubicles ${ }^{40}$. In the 1970s the efficiency approach was accompanied by recommendations to focus even more on the cowshed in order to make each dairy cow produce as much as possible, among other things by feeding the animals four times instead of twice a day. Moreover, arable farming on the dairy farm was increasingly specialized towards the production of feed for the dairy herd; the needs of good hay and silage was the priority, with feed grain a second priority. This kind of specialization in roughage made it possible to intensify dairy production, even at farms with a limited area of arable land ${ }^{41}$.

Rising yields called for more protein and energy in the feed, through improved fodder production and/or purchased feed concentrates, usually from abroad. This was relevant for the individual milk producer in the Swedish case, where commercial dairy farm-

36. Fordbruksstatistisk årsbok (1970: 244, t. 101).

37. Roos (2004: 222-26).

38. Husdjur (1970-90).

39. MARTIIN (2017).

40. Helmenius and Ekesbo (1969: 440-48). Tied-up systems dominated Swedish dairy farming throughout the studied time period.

41. Husdjur (1970-90). 
ing was based on dairy cooperatives, cooperatives which were obliged to pay for everything their members produced. Accordingly the commercialization of milk production served as a driver for purchasing of feed that would increase yield. As regards the Swedish situation it is interesting to note that the aforementioned government support in the early 1930s was accompanied by an extra tax on feed concentrates, and by the propagating for increased domestic production of nutrient rich roughage and grazing. According to contemporary farm magazines agriculture was influenced by these ideas even in the $1950 \mathrm{~s}^{42}$.

The use of feed concentrates appears to have increased in the 1960s and even more in the 1970s and 1980s. According to examples from text books on dairy farming the recommendations for rations of grains and concentrates for high lactating dairy cows (SLB breeds) were raised from 8-11 kg in 1958 to $10-12 \mathrm{~kg}$ in 1961 , and $12-14 \mathrm{~kg}$ in $1974^{43}$. Similarly recommendations for the grazing period were increasingly emphasizing feeding cows additional grains and feed concentrates and not trusting in grazing to supply nutrients ${ }^{44}$. Such figures suggest increased importing of protein, in line with current discussions, such as the study by Lassaletta et al. (2014) of 50-year trends in global movement of nitrogen $(\mathrm{N})$ through feed and food. Did intensified feeding and higher yields mean that Sweden increased its role as a driver in the global nitrogen cycle ${ }^{45}$. An approximate answer, limited to the 1970s and 1980s, is both yes and no. While the import figures are imprecise they show that the importing of feed concentrates for dairy cattle, not just for dairy cows, did actually decline and in the late 1980 s was about $80 \%$ of the level in the early 1970s. In this period, total Swedish milk production rose from 2.9 to 3.5 billion $\mathrm{kg}$ and the number of dairy cows declined from 758,000 to $576,000^{46}$. Thus fewer cows appear to have produced more on the basis of less imported feed concentrates. At the same time each cow was fed with more concentrates and contributed more to the moving of nitrogen around the globe. The suggested explanation for this is that 170,000 fewer animals meant reduced total needs for energy and protein for weight maintenance. However, the average nutrient content in farm-produced roughage was higher in the late 1980s than around 1970, which meant less feed needed to be imported ${ }^{47}$. This conclu-

42. Governmental proposition 1933/265; Lantmannen (1934, No. 8, p. 166; 1935, No. 41, p. 931). Mjölkpropagandan (1930s, annual volumes).

43. Helmenius, RydÅ and Woldmar (1958: 59); HelmeniUs and RydÅ (1961: 93); BJÄresteN (1974: 175).

44. Helmenius and Ryd̊̊ (1961: 132); Elovsson (1975: 65).

45. LASSALETta et al. (2014: 225).

46. Concentrates: Fordbruksstatistisk årsbok (1976: 114, t. 54; 1978: 99, t. 55; 1983: 87, t. 49; 1986: 74, t. 6.12; 1991: 82, t. 6.2). Milk: Statistisk årsbok för Sverige (1971: 98, t. 81; 1992: 78, t. 84). Dairy cows: Fordbruksstatistisk årsbok (1980: 251, t. 103; 1991: 140, t. 9.2).

47. Husdjur (1970-90). 
sion coincides with how Sweden is pictured on the global maps in Lassaletta et al., where a general international trend is that of increased import. The deviating Swedish behaviour can be related to its already sufficient total quantities of milk, which allowed for intensification without increased total production ${ }^{48}$.

\section{HIGH LEVELS OF CONSUMPTION}

The article will now change its focus to the consumption of milk. Attention will be paid to the phasing out of traditional use in kind and the long period of mass consumption that dominated throughout the studied period, albeit with tendencies of new kinds of demand emerging by the end.

\subsection{Traditional use in kind}

As earlier shown, the gap between total and supplied volumes diminished, and so did the use of milk in kind. Table 1 shows the phasing out of traditional forms of milk consumption in Sweden, which relates to the second of Malassis' food consumption models, pre-capitalistic consumption ${ }^{49}$.

TABLE 1

Total production, sale to dairy plants and other use (examples from 1938-39 to 1975)

\begin{tabular}{lccccccc}
\hline Year & Total production (million kilos) & \multicolumn{2}{l}{ To dairy plants } & \multicolumn{3}{c}{ Not supplied to dairy plants (million kilos) } \\
\hline & & (million kilos) & $\%$ & $\begin{array}{c}\text { Producer } \\
\text { households }\end{array}$ & $\begin{array}{c}\text { Direct sale } \\
\text { of milk }\end{array}$ & $\begin{array}{c}\text { Farm made butter } \\
\text { and cheese }\end{array}$ & $\begin{array}{c}\text { Feed } \\
\text { forcalves }\end{array}$ \\
\hline $1938-39$ & 4,714 & 3,129 & 66 & 537 & 240 & 420 & 388 \\
$1948-49$ & 4,573 & 3,541 & 77 & 457 & 170 & 140 & 265 \\
1952 & 4,198 & 3,561 & 85 & 306 & 133 & 24 & 174 \\
1961 & 3,673 & 3,263 & 89 & 179 & 67 & 7 & 157 \\
1967 & 3,214 & 2,963 & 92 & 103 & 30 & 2 & 116 \\
1975 & 3,166 & 3,023 & 95 & 55 & 8 & & 80 \\
\hline
\end{tabular}

Sources: Wahlfisk (1949: 272-73); Lebert and Åkerblom (1969: 6); fordbruksstatistisk årsbok (1983: 205, t. 137); Lind (1959: 470); Westergård (1969: 291).

48. LASSALETTA et al. (2013: 230). With higher milk yields, e.g. 8,300 kg on average (2011) the needs for more concentrated feed may have changed the proportions between imported feed concentrates and output of milk (Statistisk årsbok för Sverige, 2013: 120, t. 5.19; 121, t. 5.21).

49. MALASSIS (1988: 195). 
Farmhouse production of butter and cheese declined most drastically and had almost disappeared by the mid-1970s. This reflects the preference for mass-produced clean and modern dairy products. Similarly, the direct sale of milk ceased, due to the depopulation of the countryside and the increase in people commuting from the countryside to jobs in town where they could purchase milk and other food before going back home. In Table 1 , the figures for direct consumption in producer households also shows a decline, from $11 \%$ of total production in the late 1930 s to $4 \%$ in the mid-1970s. This is explained by lower numbers of dairy farms and fewer people per producer household. Regarding the use of whole milk as feed for calves, the decline from $8 \%$ to $3 \%$ of total production was due to the reduction in the total number of dairy cows and thus in calves, to the use of purchased milk powder, and to the strongly reduced production of veal, which had required huge amounts of milk per calf ${ }^{50}$. The averages in Table 1 do not show regional differences. In 1967, for example, sales averaged $92 \%$ and use in kind $8 \%$, but the latter was only $5 \%$ in the far south and $12 \%$ in the far north, where long distances and the lack of roads may have played a role in some regions ${ }^{51}$.

Comparisons with Denmark and Spain illustrate the differences between the approaches to dairy farming in the three countries. Denmark, which became highly commercialized early on, prioritized dairy export and used only $2.5-4 \%$ of the total production of whole milk for calves, without appreciable changes between the late 1920s and 1975. This contrasts with Spain, where $25 \%$ of the total production was used as calf feed in 1955 and about the same quantity in the early 1970s, although this was a lower share of the then higher total production ${ }^{52}$.

\subsection{Domestic consumption of marketed dairy products}

In the case of Sweden the consumption of dairy products was almost completely domestic throughout the period studied, yet the country depended on butter exports for disposal of the frequently occurring surpluses. As presented in Table 2, the major share of the Swedish milk supplied to dairy plants was actually churned into butter, with fresh milk being the second largest product and comparably small volumes being used for cheese making.

50. Production: HelmENIUS and RYDÅ (1961: 156). Consumption: Statistisk årsbok för Sverige (1929early 1960s).

51. LeBerT and ÅKerblom (1969: 10, t. 5; 12, t. 7); BÄCKLUnd (1988: 121).

52. Denmark: Landbrugsstatistik 1900-1965 (1969: 75, t. 41); Landbrugsstatistik 1990 (1991: 168, t. 12.1). Spain: Ministerio DE AgRICUlTURA (1974: 470). 
TABLE 2

Use of the milk supplied to dairy plants (\% main categories)

\begin{tabular}{lccccc}
\hline & Milk & Cream & Butter & Cheese & Total \\
\hline $1938-39$ & 29 & 7 & 56 & 8 & 100 \\
$1948-49$ & 34 & 5 & 54 & 7 & 100 \\
$1958-59$ & 31 & 9 & 49 & 11 & 100 \\
$1968-69$ & 30 & 13 & 44 & 13 & 100 \\
\hline
\end{tabular}

Sources: Wahlfisk (1949: 273); Lind (1959: 470); Westergård (1969: 291).

Commercialization did not bring about revolutionary changes in the ordinary diet because, as mentioned earlier, milk and milk products had long been part of traditional Swedish eating habits. What changed, however, was that people now consumed standardized fresh and fermented milk, cream, butter and cheese that was processed in dairy plants and purchased in town ${ }^{53}$.

FIGURE 6

Consumption of milk per person and year (Sweden, 1946-90, litres)

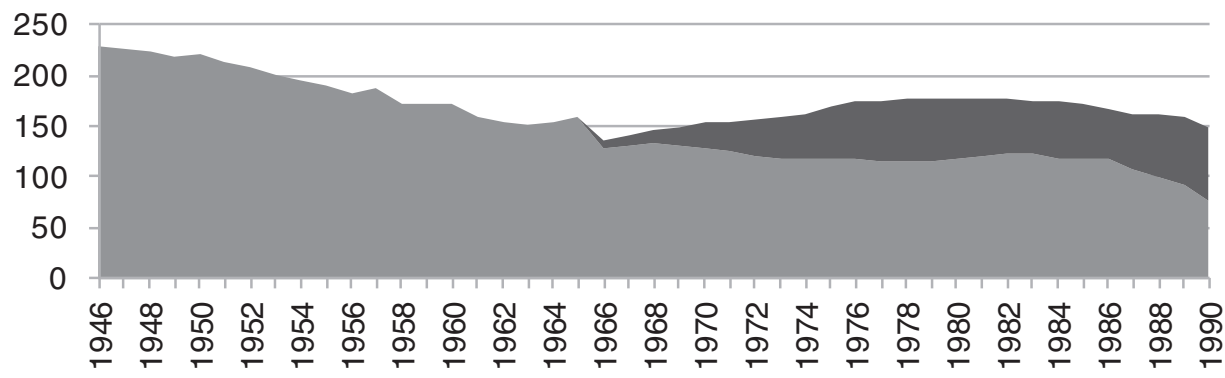

Whole milk Low fat milk

Source: Statistisk årsbok för Sverige, annual volumes.

As illustrated in Figure 6, the downward trend in milk consumption was broken in the mid-1960s when "light" products appeared. These products were also domestically produced; dairy products from global actors arrived comparably late in Sweden due to policies that protected domestic production until the 1990s.

By the turn of the twentieth century the average per capita consumption of fresh milk was about 200 litres and about 250 litres in the 1910s, while butter consumption grew

53. Grigg (1995: 250); Collantes (2015: 249); Malassis (1988: 195). 
from $4 \mathrm{~kg}$ in the late nineteenth century to $10 \mathrm{~kg}$ in the late $1920 \mathrm{~s}^{54}$. According to household surveys, the yearly per capita consumption was at a similar level in the early 1930s: 2361 milk, $7 \mathrm{~kg}$ cream, $11 \mathrm{~kg}$ butter plus $11 \mathrm{~kg}$ margarine, and $6 \mathrm{~kg}$ cheese. Milk and cheese were at the same level in the late 1940s, but the average use of butter was as much as $50 \%$ higher than in the early $1930 \mathrm{~s}^{55}$. The per capita consumption per year of milk, butter and cheese from 1946 to 1990 is shown in Figures 6-8. The figures include all types of human consumption, commercial as well as use in kind, and takes into account the population increase from 6.8 million in 1946 to 8.6 million in 1990. The pattern for the consumption of milk in the period studied can be divided into two parts, the first occurred before the mid-century when demand was relatively stable and the second part was characterized by increasing consumer saturation (Figure 6).

The per capita consumption of cream was of another scale, 6 to 8 litres per year, used in deserts, cooking and coffee. Single cream dominated in the late 1940s but its use was soon exceeded by that of double cream, which increased by about $50 \%$ until 1990 , contrasting with the demand for light milk products, which was rising at the same time.

The story of Swedish butter consumption in the twentieth century includes an antagonistic relationship with margarine. Butter export, often at an economic loss, served as a buffer to manage surplus production. Margarine instead of butter on the Swedish tables thus meant increased butter export and increased losses ${ }^{56}$. In the eyes of the dairy sector, as formulated by the Milk propaganda association, margarine was a threat to farming and the countryside, an artificial industrial product without which no surpluses of butter would exist ${ }^{57}$. In frequent campaigns the association highlighted eating, cooking and baking with butter. Moreover the dairy producers themselves were urged to consume as much butter as possible, which was promoted by a "taking-back system" through which farmers purchased refined dairy products from the dairy ${ }^{58}$.

54. Morell (1994: 233-35).

55. Household investigation (Statistisk årsbok för Sverige, 1938: 234, t. 178); 1946-90 based on Statistisk årsbok för Sverige, annual volumes.

56. These matters were, from the early 1930 s, subject to a complex system with fees, taxes on margarine and feed concentrates. As regards margarine and butter, see HELLSTRÖM (1976: 289-96). In English, MORELL (2011:211-12).

57. Mjölkpropagandan (1930, No. 7, p. 121; 1931, No. 1, p. 1; 1932, No. 3, p. 69; 1933, No. 4, p. 51; 1934, No. 4, p. 73). Swedish cultivation of oil seeds was almost non-existing in the 1920s and 1930s but was established in the 1940s and 1950s. Cooking oil was sparsely used in Swedish cooking throughout the period studied.

58. Mjölkpropagandan (1933, No. 2, p. 19; 1934, No. 4, p. 73, No. 7, p. 131). 
As regards urban consumers, they chose butter or margarine for different reasons. Less well-off households simply had to make do with cheap margarine, while better-off middle class urban households often preferred exclusive kinds of margarine instead of butter, as a marker of a modern urban life style ${ }^{59}$. As Figure 7 shows, margarine was the winner, with a decline in butter use from about 15 to $5 \mathrm{~kg}$ per person per year from 1946 to 1990.

\section{FIGURE 7}

\section{Consumption of butter and margarine (Sweden, 1946-90, kilo per person)}

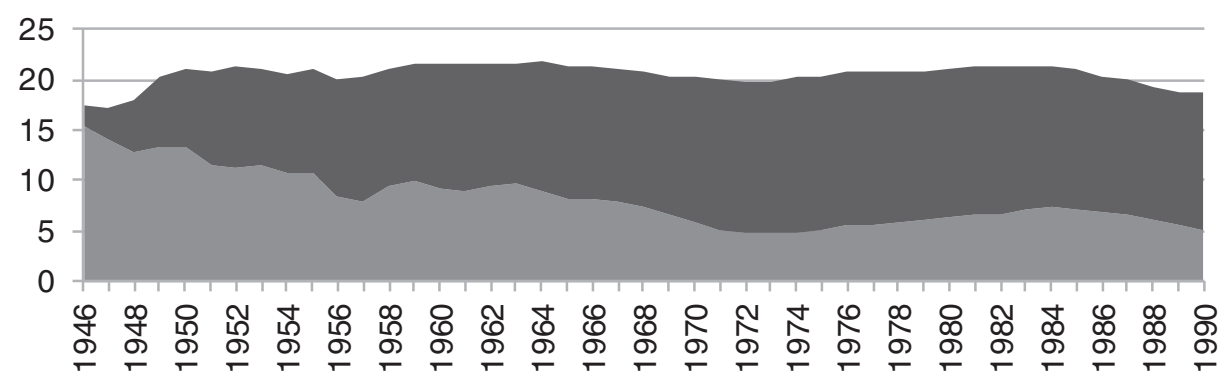

Butter Margarine

Source: Statistisk årsbok för Sverige, annual volumes.

FIGURE 8

Consumption of cheese (Sweden 1946-90, kilo per person and year)

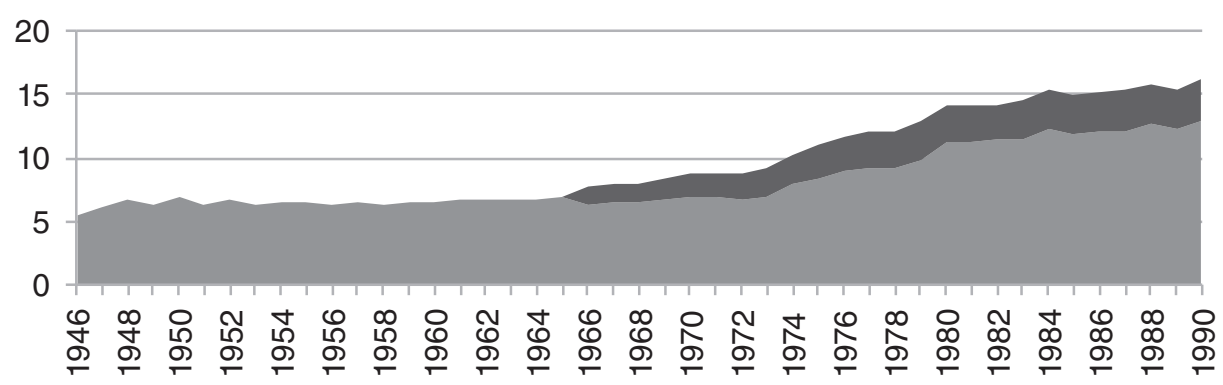

Cheeses Of which soft cheeses

Source: Statistisk årsbok för Sverige, annual volumes.

The downward trend in butter consumption contrasted with increased consumer demand for cheese. After a long stable level at about $6 \mathrm{~kg}$ per capita per year from the early 1930s to the mid-1960s, the consumption tripled up to 1990 (Figure 8). The separate records

59. Fordbruksekonomiska meddelanden (1958: 211, t. 1). 
for soft cheeses from the mid-1960s, suggest an increased demand for more processed dairy products, some of which may have been imported.

With the exception of cream and cheese, the Swedish per capita consumption of dairy products dropped over time, In Spain, according to Fernando Collantes (2015: 256), a previously low level of per capita consumption of fresh milk rose to a level in line with Swedish consumption in 1980 and exceeded it by 1990 . As for cheese, the Spanish per capita consumption quadrupled from $1.5 \mathrm{~kg}$ in 1958 to $6.3 \mathrm{~kg}$ in 1990, whereas Swedish consumption doubled, from 6.4 to $13 \mathrm{~kg}$ per year ${ }^{60}$.

\section{RELUCTANCE TO BUTTER EXPORT}

It would be misleading to claim that neither the dairy sector nor Swedish authorities cared about the imbalances between supply and demand. The calculations were in fact extensive, but there was also an acceptance of some imperfections because of the many functions other than food production that were imbedded in dairy farming. The standard way of dealing with the surplus was to export it in the form of butter, often considered a temporary solution and the least bad alternative at the time. Obviously, the Swedish approach differed greatly from the Danish. Whereas Sweden exported industrial products from manufacturing industries, mining and forestry, Denmark depended largely on export of dairy products as a main source of foreign currency.

As shown in Figure 9, the quantities exported varied greatly from year to year and between different periods. In the 1930s, as much as one third of the total butter production was exported. After the war time years in the 1940s the exported quantities continued to vary greatly, successively increasing in the 1970s and 1980s. Butter trade is complex and Figure 9 thus indicates rather than states the use of butter export as a buffer to handle Swedish surplus production of milk.

A background to Sweden's weak position in the international butter market, one that was substantially weaker than Denmark's, is found in an official report, initiated in 1928 and published in early 1930, which suggested measures to promote butter exports. In the second half of the nineteenth century and early twentieth century, Sweden had been an active, successful butter exporter, although on a smaller scale than Denmark. During the First World War and early 1920s the Swedish dairy sector was content to focus on the then

60. Collantes (2015: 256, t. 3); Statistisk årsbok för Sverige, annual volumes on total population and total consumption. 
sufficient domestic demand, but in the late 1920s the higher quantities of milk sent to the dairies exceeded domestic demand. This inspired the dairy sector to look abroad ${ }^{61}$. The come-back in the international arena was, however, somewhat disappointing. Since the 1910 s international competition had increased and so had the importers' expectations of regular deliveries of large volumes of high quality butter, which contrasted with the comparatively small and irregular Swedish quantities ${ }^{62}$.

FIGURE 9

\section{Swedish butter export as a percentage of total butter production (1927-88)}

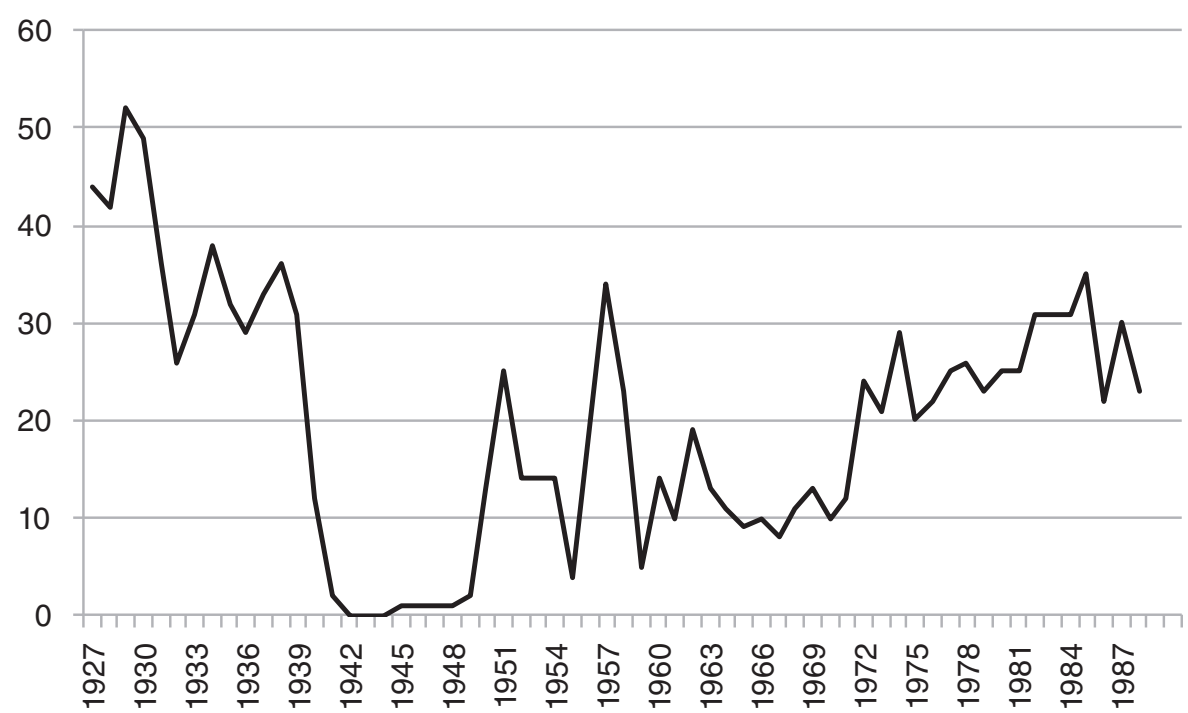

Sources: Historisk statistik för Sverige (1972: t. 3.4, 3.6); Statistisk årsbok för Sverige (1929-91).

\section{CONCLUDING DISCUSSION}

The time from the late 1920s to 1990 included expansion and contraction, increased commercialization, intensification, specialization and rationalization of the Swedish dairy sector. At the same time urbanization continued and, in discussions about marginalization of the countryside, dairy farming was often seen as an important factor with several other functions than production of food, such as a living countryside and social and emergency considerations. This contributed to a generous political approach to the side effects, such as the imbalances between supply and demand that occurred frequently, as Sweden was generally not short of a supply of dairy products. To manage overproduction, surpluses

61. SOU (1930: 2, 8); Mjölkpropagandan (1925: No. 12, p. 203).

62. SOU (1930: 9-11). 
were somewhat reluctantly churned into butter for the non-too-lucrative international market. In this context this study asks how farmers acted and responded to this vision, with focus on matters of commercialization, intensification, specialization and geographic concentration of production.

In the decades from the late 1920s until the late 1940s, dairy farming was characterized by increased degrees of commercialization, greater total volumes and volumes for sale, and a huge increase in the number of dairy suppliers. In brief, too many farmers quickly came to produce too much at the same time as the export market was problematic and the domestic consumer demand stagnating, probably earlier than in many other western European countries. This contributed to a reverse trend of fewer dairy farmers and dairy cows, a shift which was further strengthened by the large-scale societal changes in the postwar era, which made political and public attention focus on urban and industrial development at the expense of agriculture and the countryside. From the turn of the mid-century a future in dairy farming could thus no longer be taken for granted.

After achieving an almost complete degree of commercialization, the next strategy among Swedish dairy farmers was to intensify in the form of somewhat bigger dairy herds and efforts to gain a higher yield per dairy cow. The intensification was successively accompanied by increased specialization in dairy cattle only, and on the cultivation of high quality feed, instead of the previously more diverse production. As regards geographic concentration, it was found that this was chiefly a matter of there being fewer dairy farms in each parish, hence increased concentration within the local society, but with dairy farms still being found all across the country by the end of the period studied.

To conclude, almost the entire story of Swedish dairy farming from the late 1920s to 1990 took place in a context of too high an interest in production in relation to demand. The demand side had obviously been miscalculated or even ignored. Similarly the impact of technical improvements appears to have been underestimated as had farmers' response in the form of intensification and specialization to manage society's expectations of higher efficency. At the same time, intensification and specialization made dairy farmers increasingly dependent on milk, with few alternatives other than to intensify and specialize even more, or to close the barn.

Whether or not, and to what extent, the Swedish case was special or exemplifies a general western European situation is best judged by readers from abroad. For such reflections, it may be useful to consider that Sweden had dairy farmers all around the country, a cowshed at each farm holding; a long history of high consumption of dairy products; surpluses rather than shortages of dairy products; public support; and a polit- 
ical landscape that had long accepted imbalances between supply and demand, imbalances that were managed by exporting butter as a buffer.

\section{ACKNOWLEDGEMENTS}

I am very grateful to the anonymous referees of Historia Agraria for most helpful and valuable comments, and to Fernando Collantes for the initiative and work with this publication. Moreover I appreciate the comments at the Rural History conference in Girona, September 2015 where an early draft paper was presented, as well as at a HISTAGRIA seminar at the University of Santiago de Compostela in March 2016.

\section{REFERENCES}

BäCKLUND, D. (1988). I industrisamhällets utkant: Småbrukets omvandling i Lappmarken 1870-1970. Umeå: Department of Economic History, Umeå University.

BJÄresten, I. (Ed.) (1974). Husdjursskötsel. Stockholm: LT.

BJøRN, C. (Ed.) (1988). Det danske landbrugs historie. IV: 1914-1918. Odense: Landbohistorisk Selskab.

Collantes, F. (2015). Dairy Products and Shifts in Western Models of Food Consumption since 1950: A Spanish Perspective. Rural History, 26 (2), 249-68.

Collantes, F. (2016). From State-coordinated to market-oriented capitalism? A case study of Spain's dairy chain. Working Paper.

Dovring, F. (1988). Progress for Food or Food for Progress? The Political Economy of Agricultural Growth and Development. New York: Praeger.

Elovsson, B. (1975). Mjölkdjurens utfodring. Stockholm: LT.

ERLANDER, T. (1976). Tage Erlander 1955-1960. Stockholm: Tiden.

Flygare, I. A. \& IsaCson, M. (2011). The Tension between Modernity and Reality, 19452010. In J. Myrdal \& M. Morell (Eds.), The Agrarian History of Sweden: From 4000 $B C$ to $A D 2000$ (pp. 214-56). Lund: Nordic Academic Press.

FonTe, M. (2002). Food Systems, Consumption Models and Risk Perception in Late Modernity. International fournal of Sociology of Agriculture and Food, 10 (1), 13-21. http://www.ijsaf.org/contents/10-1/fonte/index.html

GRIGG, D. (1995). The Nutritional Transition in Western Europe. fournal of Historical Geography, 21 (3), 247-61. http://www.sciencedirect.com/science/article/pii/S03057 48885700187

Gulbrandsen, O. \& LindBeCK, A. (1969). Fordbruksnäringens ekonomi. Stockholm: Almqvist och Wiksell. 
Hedlund, S. \& Lundahl, M. (1985). Beredskap eller protektionism? En studie av beredskapsmålet $i$ svensk jordbrukspolitik. Malmö: Liber.

Hedlund, S. \& Lundahl, M. (1986). Emergency Considerations in Swedish Agriculture: A Retrospective look. European Review of Agricultural Economics, 13 (1), 89-105. Hellström, G. (1976). Fordbrukspolitik i industrisamhället. Stockholm: LT.

Helmenius, A \& Ekesbo, I. (1969). Nötkreatur. Stockholm: LT.

Helmenius, A. \& RYDÅ, K. (1961). Nötkreaturens utfodring och vård. Stockholm: LTK. Helmenius, A., RYdÅ, K. \& WoldmaR, G. (1959). Husdjursskötsel. Stockholm: LTK.

Historical statistics of Sweden, Part I. Population 1720-1967 (1969). Stockholm: Central Bureau of Statistics. https://gupea.ub.gu.se/handle/2077/854

Historical statistics of Sweden Part III. Foreign Trade 1732-1970 (1972). Stockholm: Central Bureau of Statistics. https://gupea.ub.gu.se/handle/2077/856

Husdjur (1970-90). Periodical.

Jansson, U. (Ed.) (2011). Agriculture and Forestry in Sweden since 1900: A Cartographic Description. Stockholm:The Royal Swedish Academy of Agriculture and Forestry. Fordbruks- och livsmedelspolitik (1984). Stockholm: Ministry of Agriculture. (SOU, 86). Fordbruksekonomiska meddelanden. (1958). Stockholm: Statens Jordbruksnämnd.

fordbruksräkningen 1961 (Census of Agriculture 1961) (1963). Stockholm: Central Bureau of Statistics.

Fordbruksstatistisk årsbok (1970, 1976, 1980, 1983, 1990, 1991). Statistical Yearbook of Agriculture. Stockholm: Central Bureau of Statistics.

Kylebäck, H. (1979). Konsument- och lantbrukskooperation i Sverige. Göteborg: Gothenburg University.

Landbrugsstatistik 1900-1965 (1969). Vol. II. Copenhagen: Danmarks Statistik.

Landbrugsstatistik 1976 (1977). Copenhagen: Danmarks statistik.

Landbrugsstatistik 1990 (1991). Copenhagen: Danmarks statistik.

Lantbruksräkningen 1981 (1983). Official Statistics of Sweden. Stockholm: Sveriges officiella statistik.

Lantmannen (1930-90). Periodical.

Lassaletta, L., Billen, G., Grizzetti, B., Garnier; J., Leach, A. M. \& Galloway, J. N. (2014) Food and Feed Trade as a Driver in the Global Nitrogen Cycle: 50-Year Trends. Biochemistry, 118 (1), 225-41. http://link.springer.com/article/10.1007/ s10533-013-9923-4

LEBERT, H. \& ÅKerblom, G. (1969). Mjölkproduktionen och dess användning 1967. fordbruksekonomiska meddelanden, 5-12.

LiND, N. (1959). Produktionen och förbrukningen av animaliska jordbruksprodukter 1958-59. Fordbruksekonomiska meddelanden, 467-80. 
MALASSIS, L. (1988). Histoire de l'agriculture, histoire de l'alimentation, histoire générale. Économie rurale, (184-86), 192-98. http://www.persee.fr/doc/ecoru_00130559_1988_num_184_1_3911

MARTIIN, C. (2005). Kor och människor: Nötkreatursskötsel och besättningsstorlekar på torp och herrgårdar 1850-1914. Uppsala: Swedish University of Agricultural Sciences. (Published as Israelsson, C.). http://pub.epsilon.slu.se/941/

Martin, C. (2008). Milk as Payment for Farm Labour:The Dairy Economy of a Swedish Estate 1874-1913. Agricultural History Review, 56 (2), 167-88. http://www. bahs.org.uk/AGHR/ARTICLES/56_203Martiin.pdf

Martin, C. (2010). Swedish Milk, a Swedish Duty: Dairy Marketing in the 1920s and 1930s. Rural History, 21 (2), 213-32. https://www.cambridge.org/core/journals/ruralhistory/article/swedish-milk-a-swedish-duty-dairy-marketing-in-the-1920s-and1930s/6D12AF056F3A1AB5D6C00C91575C8D32

MARTIIN, C. (2011). Following Trails of Cattle through the Landscape. In H. ANTONSON \& U. Jansson (Eds.), Agriculture and Forestry in Sweden since 1900: Geographical and Historical Studies (198-216). Stockholm:The Royal Swedish Academy of Agriculture and Forestry.

MARTIIN, C. (2016). Specialisation in Dairying: A Rapid Transition in Denmark and a Drawn-Out Process in Sweden. In A. ANTOINe (Ed.), Agricultural Specialisation and Rural Patterns of Development (pp. 213-32). Turnhout: Brepols.

Martin, C. (2017). Rural Electrification in Sweden: A Comparison. In P. BRASSLEY, J. BURCHARDT \& K. SAYER (Eds.), Transforming the Countryside: The Electrification of Rural Britain (pp. 157-77). Oxon: Routledge.

Mejerihantering (1913-39). Official Statistics of Sweden. Stockholm: Central Bureau of Statistics.

Ministerio De Agricultura (1974). Anuario de estadística agraria 1972. Madrid: Ministerio de Agricultura.

Mjölkpropagandan (1924-47).

Morell, M. (1994). Diet in Sweden during Industrialization, 1870-1939: Changing Trends and the Emergence of Food Policy. In J. C. BurneTt \& D. J. OdDy (Eds.), The Origins and Development of Food Policies in Europe (pp. 232-48). London: Leicester University Press.

Morell, M. (2011). Agriculture in Industrial Society, 1870-1945. In J. Myrdal \& M. Morell (Eds.), The Agrarian History of Sweden: From 4000 BC to AD 2000 (pp. 165213). Lund: Nordic Academic Press.

Myrdal, J. (2011). Farming and Feudalism 1000-1700. In J. Myrdal \& M. Morell (Eds.), The Agrarian History of Sweden: From 4000 BC to AD 2000 (pp. 71-117). Lund: Nordic Academic Press.

NM 82, Statare. Questionnaire on contract farm workers. Stockholm: Nordiska museet. 
NisKANEN, K. (1995). Godsägare, småbrukare och jordbrukets modernisering: Södermanlands län 1875-1935. Stockholm: Stockholm studies in economic history.

ODHNER, C-E. (1953). Fordbruket vid full sysselsättning. Stockholm: Kooperativa förbundets bokförlag.

Proposition No. 265, June 1933. (Governmental proposition 1933/265 to the Swedish Parliament).

Roos, A. (2004). Kontrollföreningarnas betydelse för jordbrukets utveckling. In R. RYDÉN (Ed.), fordbrukets kooperativa föreningar och intresseorganisationer $i$ ett historiskt perspektiv (pp. 221-36). Stockholm: Kungl. Skogs- och lantbruksakademien.

RäNK, G. (1966). Från mjölk till ost: Drag ur den äldre mjölkhushållningen $i$ Sverige. Stockholm: Nordiska museet.

SOU (1930). Betänkande angående vissa åtgärder för mejerihanteringens och smörexportens främjande. Sveriges Offentliga Utredningar 1930:4. Stockholm: Ministry of Agriculture.

SOU (1946). Riktlinjer för den framtida jordbrukspolitiken. Betänkande avgivet av 1942 års jordbrukskommitté, part 1. Sveriges Offentliga Utredningar 1946:42. Stockholm: Ministry of Agriculture.

SOU (1955). Det mindre jordbrukets möjligheter att uppnå bättre lönsamhet. Betänkande avgivet av småbruksutredningen. Sveriges Offentliga Utredningar1955:7. Stockholm: Ministry of Agriculture.

SOU (1977). Översyn av jordbrukspolitiken. Sveriges Offentliga Utredningar, 1977:17. Stockholm: Ministry of Agriculture.

SOU (1986). Fordbruks- och livsmedelspolitik. Sveriges Offentliga Utredningar 1984:86. Stockholm: Ministry of Agriculture.

Statistisk årsbok för Sverige (1929-1990). StatisticalYearbook of Sweden. Stockholm: Central Bureau of Statistics.

STENSGÅRD, A. (1957). Jordbrukspolitisk översikt. In Sveriges Lantbruksförbund 19171957 (pp. 103-57). Stockholm: LT.

Swedish Board of Agriculture. Historical statistical database, export, 1959-90. www.sjv.se ULMA 1. Mjölkhushållning. Questionnaire on traditional milk consumption and farm house production. Uppsala: The Institute for Language and Folklore.

WAHLFISK, K. O. (1949). Produktionen och förbrukningen av viktigare jordbruksprodukter under regleringsåret 1948-49. Fordbruksekonomiska meddelanden, 271-81.

WALLENSTEEN-JAGER, R. (1973). Mat och dryck när seklet var ungt. Stockholm: LT. WESTERGÅRD, K. (1969). Produktion och förbrukning av animaliska jordbruksprodukter 1968-69. Fordbruksekonomiska meddelanden, 289-99. 